\title{
IMPLEMENTATION OF CHARACTER EDUCATION TOWARDS A SCHOOL OF CULTURE AND ENVIRONMENTAL CARE (ADIWIYATA)
}

\author{
Norsidi ${ }^{1, *}$, Novita Sariani ${ }^{1}$ \\ ${ }^{1}$ Geography Education, Faculty of Education and Social Knowledge, IKIP-PGRI Pontianak \\ *Email: habibisukma1991@ gmail.com
}

\begin{abstract}
This study aims to determine the form of implementation of character education towards a cultured and environmentally concerned school (Adiwiyata) and the obstacles in implementing character education towards a cultured and environmentally concerned school (Adiwiyata). The method used in this research is a quantitative approach. Collecting data using a structured questionnaire with closed questions. The sampling technique used in this study was purposive sampling. The number of samples is 75 students. The research data used descriptive data analysis techniques of percentages in the form, mode, median, average, standard deviation (standard deviation). The results showed that the overall form of implementation of character education towards a cultured and environmentally concerned school (Adiwiyata) with an average score of $3.60 \%$ in the good category, students were familiar with using sinks and water faucets to wash their hands. Constraints in the Implementation of Character Education Towards Cultured and Environmentally Concerned Schools (Adiwiyata) as a whole with an average percentage score of $3.56 \%$ in the good category, are in accordance with the indicators of environmental care and Adiwiyata schools.
\end{abstract}

Keywords: Character Building; Cultural School; Environmental Care.

\section{A. INTRODUCTION}

Humans in essence and along with their physical environment have a very close relationship or dependence to meet their daily needs. Ironically, human behavior towards nature is not more environmentally wise but on the contrary does damage because it is in line with the development of modern times and the more developing and sophisticated science and technology. The quality of the physical environment decreases every year due to human actions that exploit excessive natural potential without considering the carrying capacity of the environment and its ecological functions. Some examples of environmental damage include high concentrations of greenhouse gases due to human activities that can cause climate change due to the high content of CFCs in the atmosphere which destroys the ozone layer, forest destruction, destruction of various species of flora and fauna, and erosion (Djamal \& Zoer'aini, 2005).

Lack of human concern for the natural environment is caused by the thought that excessive exploitation of nature is something that is reasonable to 
do for the fulfillment of life. In fact, by doing excessive use of the environment will have an impact on the emergence of a large enough damage to the environmental ecosystem.

The attitude of human behavior is less wise towards the environment, including throwing garbage inappropriately, cutting trees, burning forests and destroying other natural environments. Currently, there are some human beings who lack a sense of responsibility with what they have done to the environment. If this continues, the damage to the natural physical environment will be even greater. Damage to the natural environment can be overcome if humans have high awareness willing to protect the environmental ecosystem. The need for real realization of human behavior with an environmental perspective to preserve nature. All parties must be involved to play an active role in protecting the environment.

This condition needs to be encouraged to provide understanding to the younger generation so that they consciously maintain environmental awareness by cultivating directed character education in schools. One good program to implement to support environmental power in the field of education is the caring and environmental culture school program or called Adiwiyata. Komariah \& Cepi, (2016) state that school culture is a distinctive characteristic of the school which can be identified through the values adopted, attitudes held, habits displayed, and actions shown by all school personnel who form a special unit of the school system. Environmental education aims to make people more aware of environmental issues, understand human responsibility and their role for the environment, and build attitudes in environmental conservation and the ability to solve environmental problems (Amemiya et al., 1999).

Junior High School (SMP) Negeri 01 Ketapang Regency is a school that implements the Adiwiyata program in Ketapang City. The Adiwiyata program is an idea of a follow-up to an agreement between the Ministry of Environment and the Ministry of National Education in 2005 which was announced on February 21 , 2006. This is indicated by the existence of supporting data such as the principal's decree regarding the formation of the Adiwiyata Team at the school. In addition, it is also shown from the vision of the State Junior High School (SMP) 01 Ketapang Regency which contains elements of caring and environmental culture. 
The commitment of SMP Negeri 01 Ketapang Regency in realizing the vision of a school that cares about and has an environmental culture as shown in the physical condition of the school. The physical conditions of the school include the existence of gardens in front of the classrooms and school grounds, hanging pots on the school walls, and various posters inviting them to save water and energy on the walls outside the classroom. Not only that, in some corners of the school there is also a place for washing hands. Research on environmental education in several countries has been widely discussed. Finland, Spain, and Taiwan began to be interested in and consider environmental education as the basis of national education since several years ago (Yueh et al., 2010).

\section{B. MATERIALS AND METHODS}

The type used in this research is a survey using quantitative research methods. The survey research was conducted because in data collection the author collected information from the respondents through a questionnaire. The analytical method used to answer the research objectives is descriptive analysis (Nahrawai \& Ridwan, 2012). Survey research is research that takes a sample from a population and uses a questionnaire as the main data collection tool (Singarimbun \& Effendi, 2019). The sampling technique used in this study was purposive sampling. Purposive Sampling is a sampling technique with certain considerations (Sugiyono, 2012). The number of samples is 75 students. Data analysis from the results of the study was carried out using percentage descriptive data analysis techniques. Descriptive statistical analysis to describe the data obtained in the form of distribution frequency, histogram, mode, median, average, standard deviation (standard deviation) is used to categorize the average achievement obtained from the questionnaire (Seprian et al., 2020).

\section{RESULTS AND DISCUSSION}

Forms of Implementation of Character Education Towards Cultured and Environmental Care Schools (Adiwiyata) at SMP Negeri 01 Ketapang Regency

The implementation of the school policy component with environmental insight referred to as stated by the Kementerian Lingkungan Hidup dan Kementerian Pendidikan dan Kebudayaan (2011: 11-20) is the vision, mission, and goals of the school which are contained in the Education Unit Level Curriculum which contains environmental protection and management policies. 
As for the overall percentage of the results of processing questionnaires from respondents on the question item form of implementation of character education towards cultured and environmentally friendly schools (Adiwiyata) at SMP Negeri 01 Ketapang Regency in the following figure:

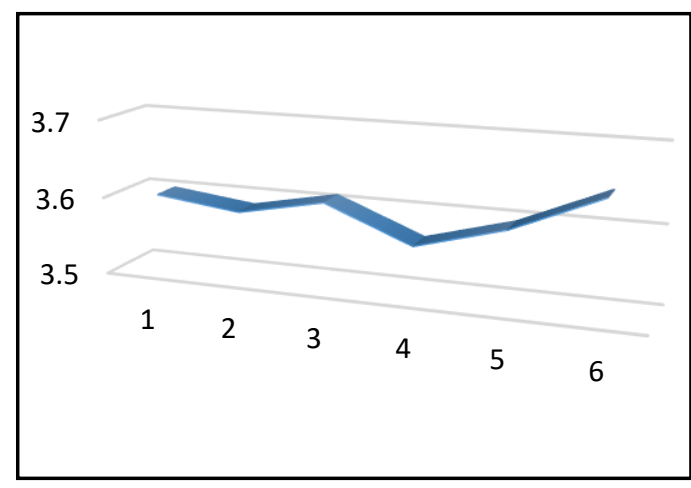

Figure 1. Percentage of Respondents' Answers

The results of the average descriptive statistical test on the teacher's question item instilled character values which included components of knowledge, awareness or willingness and action to foster environmental care towards students with an average value of $3.60 \%$. Based on the results of statistical testing, it was obtained $1.3 \%$ in the form of very poor category answers, $1.3 \%$ in the form of poor category answers, 33.3\% in the form of good category answers, and $64 \%$ in the form of very good category answers. These results indicate that the average value on the question items is categorized as good. The principal and the teacher have provided examples and demonstrated concrete actions to spark program ideas to care for the school environment to foster a caring attitude for students. The importance of the teacher's existence as a role model for the value of caring for the environment is in accordance with Peterson and Deal's statement in Zuchdi, (2011) which states that the teacher's role in character education is not only a transfer of knowledge (science), but also as a transfer of values (values).

The results of descriptive statistical testing on student question items were given guidance to become fully human beings with character in the dimensions of heart, mind, body, feeling and intention in caring for the environment with an average value of $3.60 \%$. Based on the results of statistical testing, it was obtained $0.9 \%$ in the form of very poor category answers, $2.6 \%$ in the form of poor answers, $33.3 \%$ in the form of good answers, and $63.2 \%$ in the form of very good answers. Overall, the results of the descriptive statistical test are categorized as good. Principals and teachers educate students well by always trying to provide good examples (mawidhoh). One form of exemplary action taken by teachers at SMP Negeri 01 Ketapang is by being involved in student class picket mentoring activities to support the implementation of the value of caring for 
the environment towards the Adiwiyata school of SMP Negeri 01 Ketapang. The importance of involving students in environmental awareness activities as one of the values in character education. Retno, (2012) states that character education is actually not just educating right and wrong, but includes a process of habituation of good behavior so that students can understand, feel, and want to behave well so that good character is formed.

The results of descriptive statistical testing on the question items were a conscious and serious effort from the teacher to teach environmental care character values to students with an average value of $3.60 \%$. Based on the results of statistical testing, it was obtained $0.9 \%$ in the form of very poor category answers, $3.9 \%$ in the form of poor category answers, $28.5 \%$ in the form of good category answers, and $66.7 \%$ in the form of very good category answers. Overall, the results of the descriptive statistical test are categorized as good. Teachers always try to teach character values by cultivating good habits of environmental care towards students in school. By getting used to character education caring for the environment both from individuals and even groups of people, in this case the school members themselves, especially students who are able to show good habits towards the environment, it can be said that the student has a character of attitude care well in the school environment.

The results of descriptive statistical testing on the teacher's question item created a community of environmentalists in an effort to encourage a caring attitude towards the school environment towards students with an average value of $3.60 \%$. Based on the results of statistical testing, it was obtained $0.9 \%$ in the form of very poor category answers, $3.1 \%$ in the form of poor answers, $34.6 \%$ in the form of good answers, and $61.4 \%$ in the form of very good answers. These results show that in the question item 4 students are categorized as good. The teacher encourages students to actively participate in the community of environmentalists as an effort to act in terms of caring for the environment in order to gain first-hand experience. With the existence of a community of environmentalists in schools, it is hoped that students will participate and then apply it to their personal internalization so that it becomes a good culture for application in schools.

The results of descriptive statistical testing on the item questions the teacher did develop school culture in relation to environmental care routinely, 
spontaneously, exemplary, and conditioning to students with an average value of $3.60 \%$. Based on the results of statistical testing, it was obtained $0.9 \%$ in the form of very poor category answers, $3.1 \%$ in the form of poor category answers, $31.6 \%$ in the form of good category answers, and $64.5 \%$ in the form of very good category answers. Overall, the results of the descriptive statistical test are categorized as good. The teacher cultivates a caring attitude towards the environment of students with daily routines at school by getting used to disposing of garbage in its place, using the toilet, and using the sink properly. The aspects of environmental care that are developed in schools include habituation to maintaining cleanliness and preservation of the school environment, providing garbage dumps, doing habituation to separate types of organic and inorganic waste, providing cleaning equipment, and making programs to love clean environment (Azmi \& Elfayetti, 2017).

The results of descriptive statistical testing on the teacher's question item build children's character as a strategy for the school culture process to foster student environmental care with an average value of $3.60 \%$. Based on the results of statistical testing, it was obtained $0.9 \%$ in the form of very poor category answers, $3.1 \%$ in the form of poor category answers, $34.6 \%$ in the form of good category answers, and $61.4 \%$ in the form of very good category answers. Overall, the results of the descriptive statistical test are categorized as good. In practice, students have become accustomed to using a sink and water faucet to wash their hands and use the toilet properly, although they still need guidance in practice from the teacher. Character education at the institutional level, in this case primary schools, leads to the formation of a school culture. That is, the values that are pursued for implementation, in this case caring for the environment, are expected to be the values that underlie the behavior, traditions, habits, daily life, and symbols practiced by all school members and the community (Jamal, 2012).

\section{Constraints in the Implementation of Character Education Towards Cultured and Environmental Care Schools (Adiwiyata) SMP Negeri 01 Ketapang Regency.}

The emergence of exploitation and environmental damage due to a lack of human awareness of environmental management wisely and wisely. One way to increase student awareness to understand the quality of the environment is by providing understanding and inculcating character education that is 
integrated into the school curriculum through the implementation of Adiwiyata program activities. By implementing environmental education to support the Adiwiyata program in schools, students will find it easier to apply the values they receive in the form of creativity. Developing a community with a caring character for the environment is possible to be effective through environmental education in schools (Mirza, 2015). As a place of learning, schools have a special role to play; schools can help students understand the impact of human behavior on this earth, and become a place where life is sustainable (OZSOY et al., 2012).

Overall, the average percentage of the results of research questionnaire processing from respondents on the question item is the constraints in the implementation of character education towards cultured and environmental care schools (Adiwiyata) in SMP) Negeri 01 Ketapang Regency in Figure 2 as follows:

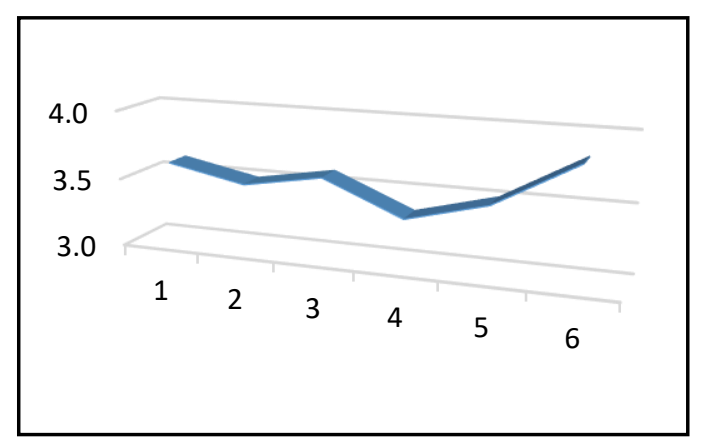

Figure 2. Percentage of Respondents' Answers

The teacher's question item provides a good example of environmental care activities in schools with an average value of $3.60 \%$. Based on the results of statistical testing, it was obtained $1.3 \%$ in the form of very poor category answers, $3.1 \%$ in the form of poor category answers, $29.4 \%$ in the form of good category answers, and $66.2 \%$ in the form of very good category answers. Overall, the results of the descriptive statistical test are categorized as good. The principal is consistent in exemplary in managing the school environment even though it is on limited land. The teacher always reminds students to do selfhabituation based on participation in environmental care. In terms of caring for the environment, the teacher shows a good overall role model for students, both in the form of situations, conditions, time and place. The Adiwiyata program is developed based on norms in life which include: togetherness, openness, equality, honesty, justice, and preservation of the functions of the environment and natural resources (Ellen, 2014).

The results of descriptive statistical testing on the teacher's question items provide subjects associated with the environment /protecting the environment with an average value of $3.50 \%$. Based on the results of statistical testing, it was obtained $1.3 \%$ in the form of very poor category answers, $3.5 \%$ in the form of poor answers, $39.9 \%$ in the form of good 
answers, and $55.3 \%$ in the form of very good answers. Overall, the results of the descriptive statistical test are categorized as good. The learning process of Environmental Education that is carried out should be a process of organizing values and clarifying concepts to foster the skills and attitudes needed to understand and appreciate the relationships between humans, culture and their physical environment (Mirza, 2015).

The results of descriptive statistical testing on the teacher's question items in learning activities have used the surrounding environment for learning with an average value of $3.60 \%$. Based on the results of statistical testing, it was obtained $1.3 \%$ in the form of very poor category answers, $3.5 \%$ in the form of poor answers, $39.9 \%$ in the form of good answers, and $55.3 \%$ in the form of very good answers. Overall, the results of the descriptive statistical test are categorized as good. The teacher is one of the human components in the teaching and learning process, which plays a role in efforts to form potential human resources in the field of development, therefore teachers are one of the elements in the field of education that must participate actively and place their position as professional staff, in accordance with the demands a growing society (Bambang, 2012). The results of descriptive statistical testing on the question items of school canteen management maintain the health and cleanliness of the food sold for consumption by students with an average value of $3.40 \%$. Based on the results of the statistical test, it was obtained $2.2 \%$ in the form of very poor category answers, $9.6 \%$ in the form of poor category answers, $39 \%$ in the form of good category answers, and $49.1 \%$ in the form of very good category answers. Overall, the results of the descriptive statistical test are categorized as good. All school members are committed to being responsible consciously in implementing environmental values. Through the Adiwiyata program, it is hoped that every school member will be involved in school activities towards a healthy environment and avoiding negative environmental impacts (Mirza, 2015).

Descriptive statistical test results in the question item students carry out class pickets well to maintain the cleanliness of the class with an average value of $3.50 \%$. Based on the results of statistical testing, it was obtained $1.3 \%$ in the form of very poor category answers, $7 \%$ in the form of poor answers, $31.6 \%$ in the form of good answers, and $49.1 \%$ in the form of very good answers. Overall, the results of the descriptive statistical test are categorized as good. The principal and the teacher 
teach each student to keep the environment clean by making class pickets distributed on a scheduled basis. The class picket program is filled with activities such as sweeping, mopping, cleaning glass, tidying the blackboard, tidying up tables and chairs, and so on. This activity is one of the ways to keep the class clean and create a comfortable and healthy climate for teaching and learning activities.

The results of descriptive statistical testing on the question item are there is a program for implementing clean Friday activities to protect the environment with an average value of $3.80 \%$. Based on the results of statistical testing, it was obtained $0.4 \%$ in the form of very poor category answers, $1.3 \%$ in the form of insufficient answers, $12.7 \%$ in the form of good answers, and $85.5 \%$ in the form of very good answers. Overall, the results of the descriptive statistical test are categorized as good. To improve the quality of education and student learning achievement, school residents carry out clean and healthy school activities with clean Friday programs for maintaining hygiene and health. Clean Friday activities are carried out according to the working group and the teacher as their companion, with routine activities including sorting organic and inorganic waste, cleaning classrooms, bathrooms and others. This clean Friday activity aims to shape the character of students who care more about loving a clean and healthy school environment.

The implementation of Character Education towards a cultured and environmentally friendly school (Adiwiyata) at SMP Negeri 01 Ketapang Regency has no obstacles for its implementation. Based on the results of the questionnaire processing obtained from the answers of respondents who were sampled in this study, in general, they have shown conformity with the indicators of the value of environmental care and Adiwiyata schools. The implementation of habitual activities, participation-based habituation, and modeling is good enough. In the implementation of environmental care character education at SMPN Negeri 01 Ketapang, the facilities and infrastructure are complete, but there are still some that are needed to support the implementation of adiwiyata-based environmental care, such as small school land which makes it difficult to plant green plants.

\section{CONCLUSIONS}

Based on the research conducted, the following conclusions can be drawn: the form of implementation of character education towards a cultured and environmentally concerned school 
(Adiwiyata) at SMP Negeri 01 Ketapang

Regency as a whole with an average percentage value of $3.60 \%$ in the good category, students have familiarized themselves with using sinks and water faucets to wash their hands. Constraints in the Implementation of Character Education Towards Cultured Schools and Care for the Environment (Adiwiyata) at SMP Negeri 01 Ketapang Regency as a whole with an average score of $3.56 \%$ in the good category, in accordance with the indicators of the value of caring for the environment and Adiwiyata schools.

\section{E. REFERENCES}

Amemiya, K., Macer, \& Darryl. (1999). Environmental Education and Environmental Behavior in Japanese Students Eubios. Journal of Asian and International Bioethics, 9, 109-115.

Azmi, F., \& Elfayetti. (2017). Analisis Sikap Peduli Lingkungan Siswa Melalui Program Adiwiyata di SMA Negeri 1 Medan. Jurnal Geografi, 9(2), 125-132.

Bambang, W. (2012). Manajemen Sumber Daya Manusia. Sulita.

Djamal, I., \& Zoer'aini. (2005). Tantangan Lingkungan \& Lansekap Hutan Kota. Bumi Aksara.

Ellen, L. (2014). Implementasi Kebijakan Adiwiyata Dalam Upaya Mewujudkan Pendidikan Lingkungan Hidup di SMA Kota Malang. Kebijakan Dan Pengembangan Pendidikan, 2(1), 82-88.

Jamal, M. A. (2012). Buku Panduan Internalisasi Pendidikan Karakter di Sekolah. Diva Press.

Komariah, A., \& Cepi, T. (2016). Visionary Leadership Menuju Sekolah Yang Efektif. Jakarta: Bumi Aksara.

Mirza, D. (2015). Mewujudkan Masyarakat Berkarakter Peduli Lingkungan Melalui Program Adiwiyata. Jurnal SOSIO DIDAKTIKA: Social Science Education, 2(1), 31-37.

Nahrawai, D., \& Ridwan, L. (2012). Analisis Kinerja Stakeholder Program Nasional Pemberdayaan Masyarakat (PNPM)-Mandiri Kelautan Perikanan Kota Ternate. Jurnal Ilmiah Platax, 1(1), 24-28.

OZSOY, S., ERTEPINAR, H., \& Necdet, S. (2012). Can Eco-Schools Improve Elementary School Students' Environmental Literacy Levels? Asia-Pacific Forum on Science Learning and Teaching, 13(2).

Retno, L. (2012). Pendidikan Karakter dalam Metode Aktif, Inovatif, \& Kreatif. Erlangga.

Seprian, P., Lahming, Moh., A. S., \& Mandra. (2020). Analisis Pelaksanaan Program Adiwiyata Di Kota Makassar. UNM Environmental Journals, 3(3), 90101.

Singarimbun, M., \& Effendi, S. (2019). Metode Penelitian Survey. LP3ES.

Sugiyono. (2012). Metode Penelitian Bisnis. CV. Alfabet.

Yueh, M.-C. M., Cowie, B., Barker, M., \& Alister, J. (2010). What influences the emergence of a new subject in schools? The case of environmental education. International Journal of Environmental \& Science Education, 5(3), 265-285.

Zuchdi, D. (2011). Pendidikan Karakter dalam PerspektifTeori dan Praktik. UNY Press. 